Research Article

Michał Skoczyński*

\title{
The Difficult alliance. Military cooperation between the ruthenian king Daniel and the Piasts of Mazovia
}

https://10.1515/openms-2020-0108

Received Jan 01, 2021; accepted Jan 07, 2021

\begin{abstract}
The article presents the military cooperation between the King of Galician-Volhynian Ruthenia, Daniel Romanowicz, and the Dukes of Mazovia, Konrad and his son Siemowit. The alliance, based as a counterweight for the cooperation between the King of Hungary and the Piast princes of Lesser Poland, who were trying to conquer Ruthenia and dominate all Piast principalities in then fragmented Poland. It lasted for several decades from the 1220's to the 1260's and was primarly aimed at mutual protection against the invasions of the pagan Yotvingians and supporting each other in armed conflicts. The text contains an analysis of war expeditions, tactics and ways of support that were given by both sides of the allianace. It is a new point of view on this aspect of political strategy of both sides that in some ways defined the regional situation. Ruthenians granted masovian Piasts some mobile and political uncommited support in fight with their relatives in Poland, and also secured their border with the Yotvingians. On the other hand, masovian knights were an additional strike force in ruthenian plundering expeditions to Yotvingia. The research was based on the analysis of preserved historical sources and scientific literature using historical methodology.
\end{abstract}

Keywords: Mazovia, Ruthenia, Galicia, Volhynia, Daniel, Konrad, Siemowit, Yotvingia, Alliance

\section{Introduction}

Kievan Rus was one of the first and most powerful state organisms created by the Slavic people. The reign of Vladimir the Great in the second half of the 10th century left a strong mark on the history of Eastern Europe, and his successor, Yaroslav the Wise, only strengthened the role that the Ruthenians played in the local conglomerate of many Christian and pagan (i.e. professing natural religions) peoples. Soon, however, the state of the Rurik dynasty was divided among the representatives of its successive generations. Increasingly smaller princely districts competed with each other and often became victims of the policies of aggressive neighbors. To counteract this, the lesser princes sought the protection of their stronger relatives and formed diverse and changing coalitions, usually under the superior prince. One such state union was ruthenian Galicia and Volhynia, which in the thirteenth and early fourteenth century was ruled by the Romanovich dynasty, descendants of Roman Mscislavovich, who died in 1205. It was undoubtedly one of the strongest districts of then Ruthenia which, however, had to deal with many war threats from Christians - Poles, Hungarians, Teutonic Order in Prussia, as well as pagans - Yotvingians, Polovtsy, Lithuanians, as well as the powerful Mongolian Empire, who after the battle of the Kalka river in 1223 subjugated the Ruthenian princes and brought them into their system of rule. It was therefore obvious for the Romanovich family to seek support in dealing with various military threats. While most of the alliances concluded in the thirteenth

\footnotetext{
*Corresponding author: Michat Skoczyński, Department of History Adam Mickiewicz University in Poznań Poznań, 60-431 Poland
}

ə Open Access. ๑ 2020 Michał Skoczyński, published by De Gruyter. @(⿶) Br This work is licensed under the Creative Commons Attribution 4.0 Public License. 
century were temporary and their arrangements were constantly changing, one of the directions of their foreign policy seems to be exceptionally permanent. Due to the geographical location of their principality (the farthest west of the districts of the former Grand Duchy of Kiev) and family connotations with the Polish Piast dynasty, the Romanovichi remained in very close relations with the district rulers of the then fragmented Poland. A particularly strong bond developed between the princes of Galicia and the Piast rulers of Mazovia ${ }^{1}$. The purpose of this article is to investigate how these allied relations developed during the reign of the Daniel Romanovich and what military significance it had for both partners.

\section{Mathods:}

The analysis will be conducted according to historical methodology and critical reading of historical sources and literature. The issue of international relations on the Ruthenian-Polish-Lithuanian-Prussian border in the thirteenth and fourteenth centuries is well-researched by Polish, Russian and Ukrainian historians. Attention was also paid to the political aspects of the alliance between Halich Ruthenia and Mazovia during this period ${ }^{2}$. However, the military aspects of this bond usually remained only on the margins of research. In identifying this problem, the preserved chronicles covering the events in this region in the period in question are of key importance, which often discuss in detail the course of expeditions of individual troops and the plans of military campaigns that individual rulers wanted to organize. Among them are the Chronicle of Galicia-Volhynia, created at the courts of the Romanovich dynasty and written in the circle of the Piast dukes, the Chronicle of Wielkopolska and the Chronicle of Dzierzwa, and a later chronicle of Jan Długosz, who probably used later lost reports from the Duchy of Masovia, deserve special attention. A certain supplement to this source base is the Chronicle of Prussia by Peter of Dusburg, which sheds light on the events of that time from the perspective of the state of the German Order in Prussia ${ }^{3}$.

\section{Results:}

Although the origins of the relationship between the Romanovichs and the rulers of Mazovia can be traced back to the marriage of Roman's father, Mscislav, with the Polish princess Agnieszka, the daughter of the last ruler of the united Poland Bolesław the Wrymouth, its actual sources seem much later. The key moment for the relationship between the two lands was the fight for the inheritance after the death of Roman of Galicia which, in addition to the Ruthenian dukes and the Hungarian king Andrzej II, also involved the Polish princes - Leszek Biały, the prince of Kraków and princeps, the nominal superior of all members of the family, and his brother Konrad , Duke of Mazovia, progenitor of this branch of the family. In his Ruthenian policy, Piastowski Princeps usually took a position similar to that represented by the Hungarian king, so in the battles for Halicz he supported his son Koloman, crowned King Of Galicia, but at the same time

1 Mykoła R. Kotljar, Z historii polityki zagranicznej książąt halickich i wołyńskich w XIII wieku, Mazowieckie Studia Humanistyczne 1-2 (2000), p. 25-40; B. Włodarski, Alians rusko-mazowiecki z drugiej polowy XIII w., w: Studia historyczne ku czci S. Kutrzeby, t. II, Kraków 1938, s. 611; D. Dąbrowski, Daniel Romanowicz. Król Rusi (ok. 1201-1264). Biografia Polityczna, Wydawnictwo Avalon, Kraków 2012; Dariusz Dąbrowski, Romanowicze a Kazimierz I Konradowic książę kujawski, in: Książę Kazimierz Konradowic i Kujawy jego czasów, ed. D. Dąbrowski, Wydawnictwo Avalon, Kraków 2017, p. 81-93.

2 M. R. Kotljar, Z historii polityki zagranicznej książąt halickich i wołyńskich w XIII wieku, Mazowieckie Studia Humanistyczne 1-2 (2000), p. 25-40; B. Włodarski, Alians rusko-mazowiecki z drugiej polowy XIII w., w: Studia historyczne ku czci S. Kutrzeby, t. II, Kraków 1938, s. 605-625; B. W ł o d ar ski, Problem jaćwiński w stosunkach polsko-ruskich, Zapiski Historyczne 24 iss. 2-3 (1959), t. 24, idem, Jatwiażskaja problema w polsko-ruskich swiaziach X-XIII w. in: Miżdunatrodnyje swiazi Rossi do XVII w.; Sbornik statiej, ed. A. A. Zimin, W. T. Paszurto, Moscow 1961, p. 116-130.

3 Kronika halicko-wołyńska. Kronika Romanowiczów, ed. D. Dąbrowski, A. Jusupovic, Wydawnictwo Avalon, Kraków 2020, Ioannis Dlugossi Annales seu Cronicae incliti Regni Poloniae. Liber 5/6, Ed. Z. Kozłowska-Budkowa, K. Pieradzka, Państwowe Wydawnictwo Naukowe, Warszawa 1973; Ioannis Dlugossi Annales seu Cronicae incliti Regni Poloniae. Liber 7/8, Ed. Z. KozłowskaBudkowa, K. Pieradzka, Państwowe Wydawnictwo Naukowe, Warszawa 1975; Kronika Wielkopolska, ed. Brygida Kurbis, Kazimierz Agbarowicz, Towarzystwo Autorów i Wydawców Prac Naukowych UNIVERSITAS, Kraków 2010; Petri de Dusburg Chronicon terrae Prussiae, ed. M. Toppen, in: Scriptores Rerum Prussicarum T.1, Verlag von S. Hirzel, Leipzig 1861, p. 21-219. 
intriguing by temporarily supporting Roman's eldest son, Prince Daniel ${ }^{4}$. Conrad, who was to mediate in 1221 between Leszek the White and Daniel, decided to warn the latter about an intrigue planned against him, thus opposing his brother and nominal superior ${ }^{5}$. It was a fateful decision and led to Konrad's political independence from Leszek. Although the Halych-Volhynian Chronicle sees its reasons in the prince's reluctance to Leszek's treacherous attitude, it is necessary to point to its more rational sources. The battles fought in Rus showed that the Duchy of Konrad was exposed to attacks by Lithuanians who allied with Daniel, moreover, the principality was constantly threatened by the Prussians living in the north. Konrad decided that it was impossible to impose sovereignty over the Galitian and Volhynian Ruthenia by the Piasts, so the most reasonable solution would be to ally with its ruler on equal terms and to fight back threats from neighboring pagan peoples together ${ }^{6}$. It cannot be ruled out that Konrad's wife Agafia also encouraged him to make such a decision. She was the daughter of the Ruthenian prince Sviatoslav and therefore the niece of Roman and cousin of Daniel. Svyatoslav was killed during the fighting in Halych, during which Leszek the White was against him, probably complicit in his death. The result of this situation was the conclusion of one of the most durable alliances in the reign of both rulers - Konrad and Daniel?

It should be noted here that the preserved source material does not allow for a complete reconstruction of the military operations of any of the Ruthenian or Polish princes. Unfortunately, the chronicles and yearbooks present only a fragment of their activities, so we can only guess at some military undertakings on the basis of indirect evidence. These may include, for example, the lack of information about subsequent pagan invasions on Mazovia in the 1320s, while in the Romanovich family there was only one attack by the Yotvingians on the vicinity of Brest, which probably took place in $1228^{8}$. In turn, in the Chronicle of Prussia of Peter of Dusburg there was an enigmatic mention, which may indicate that the Ruthenians carried out an invasion of the Prussian tribe of the Skalov, which, according to some researchers, was to take place in cooperation with Konrad of Mazovia between 1221 and $1224^{\circ}$.

For the first time, the alliance between Konrad and Daniel and his brother Vasilik found its direct reflection in the sources after the death of Leszek Biały. This is mentioned in the Chronicle of Galitia-Volhynia, which describes a joint expedition against the Prince of Greater Poland, Władysław the Spindleshanks in 1229. It was an episode of the fights between him and Konrad for supremacy over the Kraków throne and care for the heir of Leszek Biały, Bolesław the Chaste ${ }^{10}$. The expedition was to meet no resistance in the field and, without any serious fights, would reach the gord in Kalisz. Interestingly, Ruthenian reinforcements were to be much more active than Konrad's army, which, due to the opponent's inaction, scattered and began to plunder nearby gords, rushing as far as the property of the Silesian prince Henry the Pious ${ }^{11}$. It is very likely that they were encouraged to do so by the wealth of these lands, which, unlike the Ruthenian territories still devastated by fights with pagans, were at a high level of development and population density. When the troops gathered near the Kalisz stronghold, it turned out to be too powerful to take it on the march, especially in view of the little bravery of the Masovian forces. The fortifications must have made an impression on the Ruthenians, since the chronicle contains a detailed account of their construction. The ramparts of the stronghold were surrounded by a moat filled with water, as well as wooden fortifications. A drawbridge, raised with a crane, led through the moat. The whole thing was so big that on one side of the hill it was impossible to see what was happening on its other side, which made contact between the troops

4 D. Dąbrowski, Daniel. Król Rusi, p. 93-217; A. Teterycz-Puzio, Konrad I Mazowiecki, Kniaź wielki lacki (1187/89-31 sierpnia 1247), Wydawnictwo Avalon, Kraków 2019, p. 47-50, 58-62.

5 Ioannis Dlugossi Annales seu Cronicae incliti Regni Poloniae. Liber 5/6, Ed. Z. Kozłowska-Budkowa, K. Pieradzka, Państwowe Wydawnictwo Naukowe, Warszawa 1973, p. 231-232, 234, 243.

6 A. Teterycz-Puzio, Konrad I Mazowiecki, p. 58-62.

7 A. Teterycz-Puzio, Konrad I Mazowiecki, p. 47-49; H. Samsonowicz, Konrad I Mazowiecki (1187/88-31 VIII 1247, Wydawnictwo Avalon, Kraków 2014, p.67-68.

8 Kronika halicko-wołyńska, p. 136.

9 D. Dąbrowski, Daniel Romanowicz, p. 109-110.

10 Kronika Wielkopolska, ed. B. Kurbis, K. Agbarowicz, Towarzystwo Autorów i Wydawców Prac Naukowych UNIVERSITAS, Kraków 2010, p. 146-148.

11 Kronika halicko-wołyńska, p. 137. 
surrounding Kalisz difficult. Daniel and Vasilik were to divide their forces so that the stronghold would be surrounded, but the aforementioned lack of communication made a synchronized attack impossible. It was only on the next day that the attackers managed to get across the moat and set the gate and the drawbridge on fire, despite the heavy fire from the embankments and the hail of stones thrown at their heads. The attack was repulsed with heavy losses (according to the chronicler, about 160 defenders died) and the gate was put out. On the next day, the Ruthenians were preparing for the next strike by cutting down nearby trees, probably wanting to fill the moat with them. The inhabitants of Kalisz were asked to start negotiations, in which, apart from the appointed magnates Konrad, Prince Daniel (dressed as an ordinary warrior) also took part. The inhabitants of Kalisz were to put pressure on Konrad to refrain from attacking, preferring to submit to his authority as a relative of the current ruler (Władysław the Spindleshanks) than to let the warrior Ruthenians seize the gord. After Daniel revealed himself, a truce was concluded, under which the gord surrendered to Konrad's rule, and all parties to the conflict - Poles and Russians - undertook to refrain from kidnapping prisoners in future fights. It was an important turning point in mutual relations and a testimony to the political maturity of the principalities involved. This expedition was the most distant from the times of Vladimir the Great for the Ruthenian army to the west, which was also mentioned by the chronicler ${ }^{12}$. It seems that this campaign proved the great value of the Ruthenian troops in fighting in the Piast territory. The princes of Halych were not directly involved in the internal affairs of the Piasts, thanks to which their armies were efficient and punitive, unlike Konrad's subjects, whose lack of belligerence was probably due not to weakness of character, but to the complicated relations between the participants of the war. For the Ruthenian boyars, such expeditions were particularly attractive due to the richness of the loot that could more than compensate for the promise of not capturing the population. The discussed episode also shows the ability of the planned conquest of castles by the princes of Halych and their teams. After the failure of the march attack, they swiftly proceeded to a more systematic siege, while at the same time spreading fear among the defenders, who very quickly bowed to capitulation.

According to the report of the Kronika Wielkopolska, in his fight for the protection of Bolesław and the succession to the Kraków throne, Konrad was also to benefit from the help of other peoples. He was also supposed to be supported by Lithuanians, Prussians and Yotvingians, whom he was supposed to cover with his treasure ${ }^{13}$. It seems, however, that these were not ally armies, but rather mercenary teams led by their adventurer chiefs. In this context, the involvement of Ruthenians seems to have been much more valuable support.

In the 1230s, as a result of the diplomatic actions of Henryk Brodaty, who participated in the competition for the throne of Kraków, Daniel and Konrad temporarily found themselves in hostile camps. However, there is no information about their decisive actions against each other, even in 1231 during the battles in Ruthenia between Daniel and Mikhail Chernikhovski, who was opposed to him, supported by the Polovtsians and nominally also Konrad. The troops in Masovia were then limited to occupying the vicinity of the later founded gord in $\mathrm{Chełm}^{14}$. The lack of open hostility between them is best evidenced by the fact that after the invasion of the Ruthenian lands by the Tatars (Mongolians) in 1240, Daniel and his family found shelter in Mazovia, where Konrad's eldest son, Bolesław I, entrusted him with the administration of the gord in Wyszogród ${ }^{15}$.

Another testimony to the joint military actions of Konrad and Daniel concerns the battles between the Romanovichs and prince Rościsław Mikhailovich, which took place in 1245. The Prince of Galicia summoned reinforcements from all his allies, including Mazovia, who were to counterbalance the participation in the war by the troops of Bolesław the Chaste, which together with with Hungarian allies sided with Rościsław. Masovian reinforcements, similarly to Lithuanian ones, arrived too late to take part in the fighting and returned to their principality ${ }^{16}$. It is possible that this sluggishness resulted from the different nature of

12 Kronika halicko-wołyńska, p. 136-138.

13 Kronika Wielkopolska, p. 148.

14 Kronika halicko-wołyńska, p. 151-152.

15 Ioannis Dlugossi Annales seu Cronicae incliti Regni Poloniae. Liber 7/8, Ed. Kozłowska-Budkowa, Zofia Pieradzka, Krystyna, Państwowe Wydawnictwo Naukowe, Warszawa 1975, p. 11-12, Kronika Halicko-Włodzimierska, p. 193; D. Dąbrowski, Daniel Romanowicz, p. 223-224.

16 Kronika halicko-wołyńska, p. 174-176. 
the Piast rule, in which the prince did not have a permanent team that could immediately start fighting at his call, but he had to collect the knights dispersed in the principality. Apparently, however, the ruler of Mazovia did not want to waste the enthusiasm of his knights who appeared under his banner. Soon after, during Daniel's stay with the Khan of the Mongolian Horde, Konrad was to initiate a joint expedition with prince Vasilko against the Yotvingians. According to the chronicle of Galicia-Volhynia, the allied forces were, however, stopped by the harsh winter that hit the area in the winter of $1245 / 1246^{17}$. These plans were never to be realised because Konrad of Mazovia died in 1247. His death was recorded in the Chronicle of Galitia-Volhynia in the form of a very flattering note - "Konrad, the great knyaz of Lechia [Poland] who was famous and good; and Daniel and Vasilik suffered after his loss ${ }^{18}$ " Soon after, Konrad's eldest son, Bolesław, also died, and reportedly, on the advice of Daniel, he handed over his entire district to Siemowit, in opposition to the elder of his siblings, Kazimierz, Duke of Kujawy ${ }^{19}$. Despite his young age (he was 23 at the time), Siemowit had already got to know the princes of Halychyna well, and was soon to become one of their most important allies. Probably a year or two earlier he had married their relative, Princess Perejaslava (her degree of kinship with Daniel is uncertain, although it seems that she was not his daughter). There are assumptions, that archaeological signs of ruthenian presence in Siemowit's domain are the proof of Daniel's support for the young prince. Daniel's soldiers were probably in charge of protecting Mazovia from Yotvingian and Prussian strikes ${ }^{20}$. In 1247 or 1248 Siemowit personally participated in the plundering expedition to Yotvingia organized by Daniel and Vasilik. It was also attended by reinforcements from Bolesław the Shy, commanded by the Voivode of Sandomierz, Sęd ${ }^{21}$. During the expedition, the Romanovich army was supposed to be surprised by the Yotvingian tribe from Zlina, which offered the Ruthenians the chance to withdraw, because they did not consider Poles as their enemies. However, Daniel and Vasilik did not leave their allies and there was a bloody battle. It is possible that the talks conducted by the Ruthenians with Jaćwiegi were aimed at gaining time for the Polish allies. The troops were separated and camped separately, and the Masovian and Sandomierz warriors under the command of Siemowit and Sęd in the meantime fortified their camp with a wooden palisade. When they were attacked at night by the Yotvingian warband, they fiercely defended their fortifications with thrown stones, spears („sulice”) and white weapons („blades”). Apparently, however, they lacked warriors who wielded ranged weapons, so Siemowit asked Daniel to send reinforcements in the form of Ruthenian archers (,streltsy”). This support, however, arrived at the last moment to stop the enemies who had already broken the line of fortifications. Thanks to the ferocity of the Russian and Polish warriors, they managed to fight them off. It seems from the description that, despite the continuous offensive actions, the Yotvingian band managed to regroup and undertake a further plundering expedition. The allies split into three groups and formed a security formation, in which Daniel, together with Sandomierz reinforcements, formed a guard with the front, in the rear the Połowcy belonged to the Romanovich team, and in the center was Vasilik's warriors and Masovian knights. The enemy attack was supposed to break the rear guard, which was withdrawing to the positions of Vasilik and Siemowit, where another fierce confrontation took place, during which several significant members of the princely entourage were killed. Both princes were to demonstrate equal courage and bravery in this fight. Only the troops led by Daniel, withdrawing to help, drove the Yotvingians to the forest. Later in the expedition, the fights consisted mainly of partisan attacks on the allied army, which all the time pushed the main forces of the Yotvingian tribes and their Prussian allies north, as far as the Ełk River. According to the Chronicle of Galicia-Volhynia, the defenders were to acknowledge the superiority of the Ruthenian-Polish forces and, without any serious resistance, allow the plunder of a number of strongholds and the recovery of christian prisoners who were in their area ${ }^{22}$.

17 Kronika halicko-wołyńska, p. 179.

18 English translation by author.

19 Kronika halicko-wołyńska, p. 180; Ioannis Dlugossi Annales seu Cronicae incliti Regni Poloniae. Liber 7/8, Ed. KozłowskaBudkowa, Zofia Pieradzka, Krystyna, Państwowe Wydawnictwo Naukowe, Warszawa 1975, p. 62-63.

20 A. Teterycz-Puzio, Siemowit I Mazowiecki, p. 59-60.

21 Kronika halicko-wołyńska, p. 196.

22 Kronika halicko-wołyńska, s. 180-183; A. Teterycz-Puzio, Siemowit I Mazowiecki. Książę trudnego pogranicza (ok. 1215 - 23 VI 1262), Wydawnictwo Avalon, Kraków 2018, p. 58-69. 
Daniel organized another great expedition to Jaćwież in the winter of 1255/1256. This action was even more extensive this time - apart from the dukes of Halych and their Mazovian ally, Siemowit I, and reinforcements from Bolesław the Chaste of Sandomierz, it was joined by the princes of Nowogródek - Roman and Izjasław. Daniel, as the crowned king of Ruthenia, became the leader of the expedition, but despite his status he personally engaged in risky ventures, attacking the unprepared villages of Yotvingian Boldykishch and Privishch with his bodyguard. Due to a misunderstanding, planned support for these trips did not come, but thanks to the boldness of his actions, it was possible to defeat the enemies and join the main forces commanded by Vasilik and Siemowit. It should be noted here that once again Siemowit operated in the company of his brother-in-law, Prince Vasilik as part of the backbone of the allied forces of the expedition. On the one hand, this proves the great combat importance of his Mazovian troops, but perhaps also their less flexibility in the course of rough fights, in which Ruthenian warriors were better suited. Perhaps the fact that the Duke of Mazovia did not act on his own during the expedition was also associated with little war experience compared to the veteran Vasilik. It is also possible that the Romanovichi did not fully believe his skills and discipline of the Masovian army. The strength of the combined Ruthenian-Polish army was so great that, without major incidents, it plundered other villages and gords, and finally the Jotvingian envoys asked for peace, offering tribute in return and submitting to Daniel. In the following years, the threat of another expedition to Jaćwież was enough for the local chiefs to declare tribute to the king of Russia and to provide services and make their gordss available to the troops of Daniel ${ }^{23}$. This proves that thanks to decisive actions and support from the Masovian and Sandomierz allies, Romanovich achieved something that other rulers could not in previous decades - he permanently calmed the situation on the Yotvingian border by stopping the destructive invasions of local tribes on Galician Ruthenia and Mazovia.

In non-military terms, a great testimony to the mutual friendship and cooperation between Siemowit I and Daniel is the coronation of Daniel as King of Rus, which took place in Drohiczyn in 1244. Konrad blessed the only Piast prince who took part in this event, which caused rather skeptical reactions among Polish church and secular elites. In a way, Siemowit I and his father Konrad also supported the catholicization of Ruthenia, related to the coronation, by founding monasteries for Dominicans - the friars who were to become the basis for attempts to convert the Ruthenian population from Orthodoxy to Catholicism ${ }^{24}$. They were founded in Płock, Sochaczew and Warka ${ }^{25}$.

Despite these spectacular successes, the fruitful cooperation between the Mazovians and the Ruthenians was soon to end due to the great and tragic Tatar expedition to Poland and Hungary. Daniel, who had planned a war with the Mongols at the same time, fled away, not wanting to take part in this expedition. Vasilik and Leo of Galicia, due to the Tatar sovereignty over Ruthenia, were forced to support the army of the Tatar leader Burunda. The Chronicle of Galicia-Volhynia indicates that they did not do it with enthusiasm and repeatedly sabotaged some of the activities of their Mongolian superiors ${ }^{26}$. The raid was devastating and led to the fall of Lublin and Sandomierz. Although he bypassed Masovia, the situation of great confusion was used by the Lithuanian prince, Mindaugas, who sent his army to plunder the state of Siemowit I. Although the report of the Chronicle of Greater Poland mentions that the Lithuanians were supported in this action by Szwarno, Daniel's nephew, the latest research and a report closer to the events of the chronicle of Galitia-Volhynia indicates that the Greater Poland chronicler confused this raid with another, later expedition that Svarno, who was related to Mindaugas, undertaken a few years later, already as a co-ruler of Lithuania. In fact, the meals supporting the Lithuanians in 1262 had to be relatively modest, commanded by Eustace Konstantinovich, a boyar who escaped from Ryazan, and probably an adventurer in the Lithuanian service. The troops from the allied Galitian Ruthenia, as previously mentioned, were involved in the Tatar expedition, so they could not support the invaded Mazovia in any way. The Lithuanian

23 Kronika Halicko-wołyńska, p.. 197-199; A. Teterycz-Puzio, Siemowit I Mazowiecki, p. 71-76.

24 Ioannis Dlugossi Annales seu Cronicae incliti Regni Poloniae. Liber 7/8, Ed. Zofia Kozłowska-Budkowa, Krystyna Pieradzka, Państwowe Wydawnictwo Naukowe, Warszawa 1975, p. 57-58; Kronika halicko-wołyńska p. 192-193.

25 M. Skoczyński, Contrata Masoviae. Dominikańskie klasztory na Mazowszu w XIII-XVI w., Wydawnictwo Polskiej Prowincji Dominikanów W DRODZE, Poznań 2018, p. 74-77.

26 Ioannis Dlugossi Annales seu Cronicae incliti Regni Poloniae. Liber 7/8, Ed. Z. Kozłowska-Budkowa, K Pieradzka, Państwowe Wydawnictwo Naukowe, Warszawa 1975, p. 61; Kronika Wielkopolska, p. 187-188. 
expedition divided into two groups, the first of which focused on the sacking of the gord of Płock and the northern part of the principality. The second group attacked the areas on the left bank of the Vistula, probably to stop the prince's attempts to organize a force that could carry out a counterattack. The culmination of these activities was the siege of the ducal residence in the gord of Jazdów (in today's Warsaw). Concluding from the accounts of Polish chronicles, there was a betrayal, which caused the Lithuanian warriors to invade the area of the stronghold, capture the prince and his son Konrad, and then the prince was to be murdered (perhaps by Eustace Konstantinovich himself?), And his remains were burned together with the captured stronghold. Presumably, the same armed men later attacked the territory of Vasilik, who was then on an expedition with the Mongols and was unable to effectively resist ${ }^{27}$.

After the death of Siemowit I and the release of the minor Konrad II from captivity, power in Mazovia was taken over by the widow of the murdered prince, Perejasław, a relative of the Romanovich family. She asked the Duke of Greater Poland, Bolesław the Pious, for help in defending the principality, who in the following years fought off Lithuanian and Prussian invasions, and for a short time entered into an armed conflict with Wasylek and Schvarno ${ }^{28}$. Fortunately, the misunderstandings were quickly resolved and the balance between Masovia and Ruthenia was restored. Before that happened, however, Daniel Romanovich, the king of Ruthenia, died ${ }^{29}$. Thus, an epoch ended in the mutual relations between the two state organisms. Mazovia, divided between the sons of Siemowit I, never became a single, strong principality, and despite several episodes of fighting for leadership among the Piast princes, it remained rather a periphery. The same is true of Galicia and Volhynia, which in the following decades did not manage to regain its leading role among the Rurikovich family. In the fourteenth century, there was a short reign in Galicia and Volhynia of the Piast prince from the Masovian line, Bolesław Jerzy Trojdenowicz, but soon these duchies fell under the rule of the Polish kings ${ }^{30}$.

\section{Discussion:}

Taking into account the reign of Daniel Romanovich, it can be seen that the relationship with Mazovia was then an important element of foreign policy. This alliance lasted for about forty years (with a short break in the 1930s), but it did not find reflection in too many journeys noted by chroniclers. Only two military expeditions with the participation of Konrad of Mazovia are mentioned (one was carried out on his initiative to Wielkopolska and the other, unrealized, to Yothvingia in 1252, as well as two expeditions with Siemowit I to Yothvingia. This can be interpreted in two ways. they ignored those military operations that were less successful or spectacular and thus did not fulfill the basic task of the chronicle, which was to glorify the ancestors of its patrons - the ruling family. It is also possible that the mere fact of the declared alliance was a sufficient tool to deter potential enemies, in particular the pagan Yothvingians and the Prussians from plundering expeditions to the lands of Galicia Ruthenia and Mazovia. At this point, it is also necessary to assess the military value and nature of military cooperation of the princes and the universal segment of the allied troops, while the Poles will give the opponent a more static but difficult force. It is impossible to ignore the key factor, which was the different circumstances of the acquisition of combat skills by warriors and knights. Masovians, although they had to face pagan tribes from Yothvingia,

27 Kronika halicko-wołyńska, p. 213-214; Ioannis Dlugossi Annales seu Cronicae incliti Regni Poloniae. Liber 7/8, Ed. KozłowskaBudkowa, Zofia Pieradzka, Krystyna, Państwowe Wydawnictwo Naukowe, Warszawa 1975, p. 125-127; Kronika Wielkopolska, p. 188-189, 191.

28 A. Teterycz-Puzio, Bolesław II Mazowiecki. Na szlakach ku jedności (ok. 1253/58 - 24 IV 1313), Wydawnictwo Avalon, Kraków 2015, p. 33-39.

29 Kronika Wielkopolska, p. 197; Kronika halicko-wołyńska, p. 219.

30 E. Wójcikowska, Słowo o Bolesławie Jerzym II Trojdenowiczu (1310-1340) - ostatnim Romanowiczu na tronie halickowłodzimierskim, Sensue Historiae 18 (2015/1); B. Włodarski, Wołyń pod rządami Rurykowiczów i Bolesława Jerzego Trojdenowiecza, Rocznik Wołyński 3 (1934); L. Wojtowycz, Walka o spadek po Romanowiczach a król polski Kazimierz III Wielki, in: Kazimierz Wielki i jego państwo, ed. J. Maciejewski, T. Nowakowski, Wydawnictwo Uniwersytetu Kazimierza Wielkiego, Bydgoszcz 2011; Jan Tęgowski, Okoliczności wstąpienia na tron halicko-włodzimierski Piasta mazowieckiego Bolesława Trojdenowica (nieznane dokumenty ruskie z XIV wieku), STUDIA PODLASKIE 18 (2009/2010), p. 313-327. 
Prussia and Lithuania more than once, they also often confronted with armies operating in a style more similar to western european. The troops serving Henryk the Pious or Władysław the Spindleshanks should be considered such opponents. The Ruthenians, in turn, had to maintain greater flexibility and dynamics of their warfare, in which they faced not only the already mentioned pagan peoples (in addition to the already mentioned Baltic peoples, they also faced the Polovtsians), but also the major powers of that time - the Mongols, Hungarians and, occasionally, also Czechs and the armies of the rulers of German countries. It was probably these slightly different experiences that made the Ruthenians superior, for example in rifle units (which was revealed in the first expedition to Yotvingia), but they also performed better in dynamic raids on enemy territory. For Konrad of Masovia, an additional value of the Ruthenian troops was their lack of political involvement in local Polish affairs, which made them a dangerous tool for ravaging the property of the Piast princes who were hostile to him. They constituted a force more willing to fight against the Polish knighthood than the Mazovian people who were often related to them. In addition, their reputation of raiders from the east meant that, for example, the defenders of the gord in Kalisz feared Daniel and Vasilik more than Konrad, who also had a reputation for being impetuous, but was already well known and more predictable in his behavior.

Summarizing the above analyses, the alliance of the princes of Galicia and Masovia during the reign of Daniel Romanovich was an important strategic element in the life of the region. Although not much can be said about the tactics used and the mutual military commitment, it seems that the complementary potentials of both armies jointly created a new quality, strongly deterring the Yotvingian tribes. Thanks to bringing the Teutonic Order to Prussia and the temporary Christianization of the ruler of Lithuania, other threats from the pagan neighbors in the north were not so dangerous. Despite the death of the closely related leaders - Konrad of Masovia, Daniel Romanovich and Siemowit Konradowic, the bond between these family lines survived for many more years, so it can be said that the rough friendship of Konrad and Daniel, initiated in 1221, left its mark on the military history of the entire region for over more than century.

\section{References}

Ioannis Dlugossi Annales seu Cronicae incliti Regni Poloniae. Liber 5/6, Ed. Kozłowska-Budkowa, Zofia Pieradzka, Krystyna, Państwowe Wydawnictwo Naukowe, Warszawa 1973

Ioannis Dlugossi Annales seu Cronicae incliti Regni Poloniae. Liber 7/8, Ed. Z. Kozłowska-Budkowa, K. Pieradzka, Państwowe Wydawnictwo Naukowe, Warszawa 1975

Kronika Halicko-wołyńska. Kronika Romanowiczów, ed. D. Dąbrowski, A. Jusupovic, Wydawnictwo Avalon, Kraków 2020,

Kronika Wielkopolska, ed. B. Kurbis, K. Agbarowicz, Towarzystwo Autorów i Wydawców Prac Naukowych UNIVERSITAS, Kraków 2010

Petri de Dusburg Chronicon terrae Prussiae, ed. M. Toppen, in: Scriptores Rerum Prussicarum T.1, Verlag von S. Hirzel, Leipzig 1861, p. 21-219.

D. Dąbrowski, Daniel Romanowicz. Król Rusi (ok. 1201-1264). Biografia Polityczna, Wydawnictwo Avalon, Kraków 2012

D. Dąbrowski, Romanowicze a Kazimierz I Konradowic książę kujawski, in: Książę Kazimierz Konradowic i Kujawy jego czasów, ed. D. Dąbrowski, Wydawnictwo Avalon, Kraków 2017

M. R. Kotljar, Z historii polityki zagranicznej książąt halickich i wołyńskich w XIII wieku, Mazowieckie Studia Humanistyczne 1-2 (2000),

H. Samsonowicz, Konrad I Mazowiecki (1187/88-31 VIII 1247, p.67-68Wydawnictwo Avalon, Kraków 2014

M. Skoczyński, Contrata Masoviae. Dominikańskie klasztory na Mazowszu w XIII-XVI w., Wydawnictwo Polskiej Prowincji Dominikanów W DRODZE, Poznań 2018

A. Teterycz-Puzio, Bolesław II Mazowiecki. Na szlakach ku jedności (ok. 1253/58 - 24 IV 1313), Wydawnictwo Avalon, Kraków 2015,

A. Teterycz-Puzio, Konrad I Mazowiecki, Kniaź wielki lacki (1187/89-31 sierpnia 1247), Wydawnictwo Avalon, Kraków 2019 
A. Teterycz-Puzio, Siemowit I Mazowiecki. Książę trudnego pogranicza (ok. 1215 - 23 VI 1262), Wydawnictwo Avalon, Kraków 2018

J. Tęgowski, Okoliczności wstąpienia na tron halicko-włodzimierski Piasta mazowieckiego Bolesława Trojdenowica (nieznane dokumenty ruskie z XIV wieku), STUDIA PODLASKIE 18 (2009/2010)

B. Włodarski, Alians rusko-mazowiecki z drugiej polowy XIII w., w: Studia historyczne ku czci S. Kutrzeby, t. II, Kraków 1938

B. Włodarski, Problem jaćwiński w stosunkach polsko-ruskich, Zapiski Historyczne 24 iss. 2-3 (1959), t. 24

B. Włodarski, Jatwiażskaja problema w polsko-ruskich swiaziach X-XIII w. in: Miżdunatrodnyje swiazi Rossi do XVII w.; Sbornik statiej, ed. A. A. Zimin, W. T. Paszurto, Moscow 1961,

B. Włodarski, Wołyń pod rządami Rurykowiczów i Bolesława Jerzego Trojdenowiecza, Rocznik Wołyński 3 (1934);

L. Wojtowycz, Walka o spadek po Romanowiczach a król polski Kazimierz III Wielki, in: Kazimierz Wielki i jego państwo, ed. J. Maciejewski, T. Nowakowski, Wydawnictwo Uniwersytetu Kazimierza Wielkiego, Bydgoszcz 2011

E. Wójcikowska, Słowo o Bolesławie Jerzym II Trojdenowiczu (1310-1340) - ostatnim Romanowiczu na tronie halicko-włodzimierskim, Sensue Historiae 18 (2015/1) 